\section{Weed Control in a Newly Established Organic Vineyard}

\author{
Mercy Olmstead ${ }^{1,4}$, Timothy W. Miller ${ }^{2}$, Callie S. Bolton ${ }^{2}$, \\ and Carol A. Miles ${ }^{3}$
}

\begin{abstract}
ADDITIONAL INDEX WORDS. grapes, Vitis vinifera, cover crop, cultivation, Pisum sativum, Triticum aestivum
\end{abstract}

Summary. Consumer demand for organic and sustainably produced products has increased the interest in organic wine grape (Vitis vinifera) production. However, organic production can be challenging, and weed management is a critical issue during the establishment of an organic vineyard. In 2009, the effectiveness of five cover crop treatments and cultivation regimes was evaluated for two years for weed control in a newly established organic vineyard of 'Pinot noir précoce' and 'Madeleine angevine' grape cultivars in northwestern Washington State. Alleyway management treatments were cultivation in alleyways with hand weeding in the vine row (control), grass cover crop which included perennial ryegrass (Lolium perenne ssp. perenne) and red fescue (Festuca rubra ssp. arenaria) seeded in the alleyway and in-row tillage with a specialty offset-type cultivator, winter wheat (Triticum aestivum) cover crop with in-row string-trimming, austrian winter pea (Pisum sativum ssp. sativum var. arvense) cover crop with in-row string-trimming, and winter wheat-austrian winter pea cover crop mix with in-row string-trimming. In 2009 , weed dry biomass was lowest in the alleyway of the control $\left(0.8 \mathrm{~g} \cdot \mathrm{m}^{-2}\right)$ and offset cultivator treatments $\left(6.3 \mathrm{~g} \cdot \mathrm{m}^{-2}\right)$ on 3 Aug. and tended to be lowest in the alleyway of the control $\left(4.8 \mathrm{~g} \cdot \mathrm{m}^{-2}\right)$ and offset cultivator treatments $\left(16.0 \mathrm{~g} \cdot \mathrm{m}^{-2}\right)$ on $27 \mathrm{Sept}$. In the second year of establishment (2010), winter wheat and austrian winter pea were eliminated from the plots by mid-July, and white clover (Trifolium repens) and perennial ryegrass were the dominant weed species and accounted for a majority of the total weeds. On average over the two-year period, the control treatment required the most time for alleyway management $\left(92 \mathrm{~h} \cdot \mathrm{ha}^{-1}\right)$ followed by the offset cultivator treatment $\left(64 \mathrm{~h} \cdot \mathrm{ha}^{-1}\right)$, while the winter wheat, austrian winter pea, and winter wheat-austrian winter pea mixture required 32 to $42 \mathrm{~h} \cdot \mathrm{ha}^{-1}$. 'Madeline angevine' produced more shoot growth than 'Pinot noir précoce' in Sept. 2010 (42.3 and $25.9 \mathrm{~cm}$ respectively), and shoot growth of both cultivars in the control treatment was significantly longer $(125.0 \mathrm{~cm})$ than under any other treatment $(55.4$ to $93.0 \mathrm{~cm})$, illustrating the importance of weed control during vineyard establishment. In this study, the most effective weed management regime, although also the most time consuming, included a vegetative-free zone around the vines (e.g., in-row) maintained by hand weeding and a cultivated alleyway.

I nterest in sustainable and organic production systems has increased worldwide, particularly in viticulture as fresh and processed grapes are

Funding for this study was provided by the Wash ington State University Center for Sustaining Agriculture and Natural Resources, Washington State Commission for Pesticide Registration, Washington Wine Advisory Committee, and Northwest Agriculture Research Foundation.

The technical assistance of Jonathan Roozen is gratefully acknowledged.

${ }^{1}$ Department of Horticultural Sciences, University of Florida, P.O. Box 110690, Gainesville, FL 326110690

${ }^{2}$ Department of Crop and Soil Sciences, Washington State University, Northwestern Washington Research and Extension Center, 16650 State Route 536, Mount Vernon, WA 98273-4768

${ }^{3}$ Department of Horticulture, Washington State University, Northwestern Washington Research and Extension Center, 16650 State Route 536, Mount Vernon, WA 98273-4768

${ }^{4}$ Corresponding author. E-mail: mercyl@ufl.edu. one of the major organic fruit crops worldwide (Granatstein et al., 2010; Willer and Kilcher, 2009). Environmental concerns regarding increased soil erosion, decreased soil fertility, limited water supply, biodiversity loss, and herbicide resistance have led growers to consider minimal input production systems (Krauss et al., 2010; Lal et al., 2007; Montgomery,
2007; Triplett and Dick, 2008). In addition, organic vineyard production systems have been found to preserve biodiversity of yeast strains associated with wine production (Cordero-Bueso et al., 2011). However, weed management is the most expensive and technically challenging practice for organic grape production (Dufour, 2006; Guthman, 2000), and many organic farmers rely on mechanical and hand cultivation for weed control. Although these methods are highly effective, they are also laborintensive, more expensive, and their sustainability is questionable from a labor and environmental perspective (Guthman, 2000; White, 1996). Alternative practices that promote sustainability include the use of cover crops, mulches, reduced or no-tillage, and organic herbicides (Altieri, 1995). These techniques have resulted in wines with quality comparable or superior to conventionally managed grapes (Stolz and Schmid, 2007), sometimes resulting in higher prices for wines produced with organic grapes (Delmas and Grant, 2010).

Although there are many benefits to using cover crops, their primary use has been as an alternative weed suppression technique in organic and conventional vineyards worldwide (Dastgheib and Frampton, 2000; Liebman and Davis, 2000; McGourty, 2004; Pardini et al., 2002). Cover cropping can also improve soil organic matter, increase nutrient levels, improve soil structure, and increase earthworm populations, resulting in improved soil quality (Davies et al., 2001; Gulick et al., 1994; Nevens and Reheul, 2002; Paoletti et al., 1998; Pimentel et al., 2005; Tan and Crabtree, 1990). Incorporation of mowed grass cover crop residue increases organic matter, releases nitrogen and potassium into the soil, and increases soil pH (Ripoche et al., 2011; Snapp and Borden, 2005). Remaining stubble of

\begin{tabular}{llll}
\hline $\begin{array}{l}\text { Units } \\
\text { To convert U.S. to SI, } \\
\text { multiply by }\end{array}$ & U.S. unit & SI unit & $\begin{array}{l}\text { To convert SI to U.S., } \\
\text { multiply by }\end{array}$ \\
\hline 0.4047 & acre $(\mathrm{s})$ & $\mathrm{ha}$ & 2.4711 \\
0.3048 & $\mathrm{ft}$ & $\mathrm{m}$ & 3.2808 \\
3.7854 & gal & $\mathrm{L}$ & 0.2642 \\
2.54 & inch $(\mathrm{es})$ & $\mathrm{cm}$ & 0.3937 \\
0.4536 & $\mathrm{lb}$ & $\mathrm{kg}$ & 2.2046 \\
1.1209 & $\mathrm{lb} / \mathrm{acre}$ & $\mathrm{kg} \cdot \mathrm{ha}^{-1}$ & 0.8922 \\
305.1517 & $\mathrm{oz} / \mathrm{ft}^{2}$ & $\mathrm{~g} \cdot \mathrm{m}^{-2}$ & 0.0033 \\
$\left({ }^{\circ} \mathrm{F}-32\right) \div 1.8$ & ${ }^{\circ} \mathrm{F}$ & ${ }^{\circ} \mathrm{C}$ & $\left({ }^{\circ} \mathrm{C} \times 1.8\right)+32$ \\
& & &
\end{tabular}


a grass cover crop also allows for greater solar radiation absorption by the soil, and provides traction for equipment (Bugg et al., 1996; Gaffney and Van Der Grinten, 1991), both important benefits in a cool, maritime climate. Weed suppression by cover cropping can be achieved in production systems with grass, legume, or grass/ legume mixes (Akemo et al., 2000).

Winter wheat and perennial ryegrass are common vineyard cover crops in Washington State (Olmstead et al., 2001). In western Oregon, with similar climate and soil properties as western Washington, five different mixtures of cover crops demonstrated low competition with mature 'Pinot noir' grapevines (Sweet and Schreiner, 2010), although effects on weed growth were not reported. Cover crop selections and stand establishment are particularly important in newly established vineyards as young vine growth can be more susceptible to cover crop competition (Bordelon and Weller, 1997). Since young vines have limited nutrient and carbohydrate reserves, cover crops for young vineyards must be less competitive than those for established vineyards (Balerdi, 1972; Byrne and Howell, 1978; Eastham et al., 1996).

Mulching can be an effective weed suppression tool, as found when mulched winter cereal rye (Secale cereale) and crimson clover (Trifolium incarnatum) residues reduced in-row weed cover to $5 \%$ or less in a young 'Chardonnay' vineyard in western Oregon (Fredrikson et al., 2011). Mulches composed of legumes can break down more quickly, while those comprised of grasses break down more slowly, providing sustained weed suppression (Teasdale and Mohler, 1993). Ideal stand establishment of the cover crop and proper timing of mulching into vine rows can suppress weed populations as well as or better than conventional tillage systems in vineyards (Steinmaus et al., 2008), predominantly through the exclusion of light required for seed germination (Buhler, 1997).

Cultivation is the traditional method for weed removal in organic systems, and specialty cultivators can be used to reduce in-row weed populations with minimal vine damage. Several in-row cultivators specifically designed for orchard and vineyard use are the Wonder Weeder (Harris
Manufacturing, Burbank, WA), Weed Badger $^{\circledR}$ (Weed Badger Division, Marion, ND), and the French plow. Although these implements are able to cultivate more closely to the vine row than standard cultivators, the area immediately around the vines still requires manual weeding (Zabadal, 1999). The objective of this study was to compare the efficacy of traditional organic vineyard weed management techniques with four cover crop and tillage regimes for weed suppression in a newly planted vineyard in transition to organic production.

\section{Materials and methods}

A 3.0-acre vineyard was established in 2009 at the Washington State University (WSU) Northwest Washington Research and Extension Center (NWREC) in Mount Vernon, WA. Mount Vernon is in the Puget Sound American Viticultural Area and has low growing degree-days (1300-1600 at $\geq 50{ }^{\circ} \mathrm{F}$ ), cool, dry summers $\left(50\right.$ to $68{ }^{\circ} \mathrm{F}$ and 3 to 6 inches precipitation) and mild, wet winters (21 to $40{ }^{\circ} \mathrm{F}$ and 20 to 26 inches precipitation) (AgWeather Net; Washington State University, 2011). The soil type is a Skagit Series soil (fine-silty, mixed, superactive, nonacid, and mesic Fluvaquentic Endoaquepts). The vineyard was established to achieve organic certification using trellis and irrigation materials listed with the Organic Materials Review Institute, and was managed accordingly (Washington State Department of Agriculture, 2012).

The experiment was a balanced split-plot design with main plots arranged in a randomized complete block design comprised of three replications. Main plots were weed suppression treatments and were nine rows wide and 84 ft long, with 14 plants per row. Rows were $8 \mathrm{ft}$ apart and vines were spaced $6 \mathrm{ft}$ apart in the row. Alleyway management treatments were instituted at the time of vineyard establishment and consisted of a standard treatment with clean cultivation provided by tillage in the alleyway and hand weeding in the row, a companion cover crop mix comprised of 75\% 'Gator III' dwarf perennial ryegrass and $25 \%$ 'Osbeck' creeping red fescue with mowing in the alleyway and in-row tillage with a Lilliston spider-type offset cultivator (Wonder Weeder, Harris Manufacturing,
Burbank, WA) in addition to separate plantings of winter wheat, austrian winter pea, and a combination of winter wheat and austrian winter pea (2:1). Winter wheat, austrian winter pea, and the winter wheat-austrian winter pea mixture were mowed in the alleyway and in-row weeds were controlled with a handheld stringtrimmer. Non-treated winter wheat and austrian winter pea cover crop seed purchased from Peaceful Valley Farm \& Garden Supply (Grass Valley, CA) in 2009 and Pacific Northwest Farmers' Cooperative (Genesee, ID) in 2010 were seeded in winter wheat (300 lb/acre), austrian winter pea (300 lb/acre), and winter wheataustrian winter pea mixture plots (200:100 lb/acre), respectively, using a backpack cyclone spreader (Wilbur-Ellis Co., San Francisco, CA) on 30 June 2009 and on 23 Mar. 2010. Soil had been freshly tilled and was vegetation-free at the time of the 2009 seeding. Soil had been disked once and rototilled twice before the 2010 seeding, although moist soil allowed many of the weeds to survive tillage operations. Seeds were incorporated 1 to 2 inches into the soil, using a chain drag and roller attachment (fabricated on-farm) to an allterrain vehicle. Companion grass mix (Peaceful Valley Farm \& Garden Supply) was seeded using an Ortho ${ }^{\circledR}$ Whirly-bird Spreader (Scotts, Marysville, $\mathrm{OH}$ ) at $10 \mathrm{lb} /$ acre in July 2009, but due to insufficient establishment, it was reseeded at $13 \mathrm{lb} /$ acre in Mar. 2010. Alleyway management differed by weed suppression treatment, with the control alleyway tilled, while all other treatments containing a cover crop or mixture were mowed at regular intervals.

Subplots included two wine grape cultivars, Madeleine angevine (four rows) and Pinot noir précoce (five rows), both well suited to the region (Moulton and King, 2005), and grafted on Couderc 3309 rootstock. 'Madeleine angevine' is an early ripening French white wine grape from a presumed cross between 'Madeleine royale' and 'Malingre precoce' or 'Circé' (Vargas et al., 2009). 'Pinot noir précoce' ('Pinot madeleine') is an early ripening wine grape resulting from a mutation of 'Pinot noir' (Konrad et al., 2003). The vineyard was amended for nitrogen, phosphorus, and potassium based on preplant soil 
tests (Bolton, 2011), and dormant grafted vines were hand transplanted in June 2009. All vines were trained to a spur pruned, bilateral cordon system. Five vines were randomly selected and flagged for data collection within each subplot. Shoot length was measured from the base of the shoot to the shoot tip in both years. Pruning weights were collected as vines were pruned to two nodes on 16 to 18 Feb. 2010 and on 21 Jan. 2011.

Vines were drip-irrigated (18 mm emitters, $0.55 \mathrm{gal} / \mathrm{h}$; Point Source Irrigation, Fresno, CA) for 3-h intervals twice per week from 1 June through 1 Sept. 2009, and from 6 July until 1 Sept. 2010. Total irrigation application in 2009 was 46 gal and 33 gal in 2010. In 2009, the vineyard was fertigated with $4.7 \mathrm{gal} / \mathrm{h}$ of $6 \mathrm{~N}-0 \mathrm{P}-0 \mathrm{~K}$ (Vegan Nitrogen, Westbridge Agricultural Products, Vista, CA) on 30 June, 7 July, and 21 July. In 2010, the vineyard was fertigated with $5.4 \mathrm{gal} / \mathrm{h}$ of $4 \mathrm{~N}-0.9 \mathrm{P}-3.3 \mathrm{~K}$ fish fertilizer (Phytamin; California Organic Fertilizers, Fresno, CA) on 27 July and 3 Aug. Vegetation management treatments were initiated when cover crop or weeds were $30 \mathrm{~cm}$ tall. Hand weeding was done in-row in the control and offset cultivator treatments on 21 July and 13 Aug. of 2009 and on 1 June, 29 June, and 11 Aug. of 2010. String-trimming vegetation to the soil level was used under the vines in winter wheat, austrian winter pea, and winter wheataustrian winter pea mixture on 11 Aug. 2009, and on 14 May, 14 June, 6 July, and 3 Aug. 2010. Alleyways were cultivated in the control treatment on 8 Sept. and 7 Oct. 2009, and on 21 June, 3 Aug., and 14 Oct. 2010. Vegetation was mowed to a height of 2 inches in winter wheat, austrian winter pea, and winter wheataustrian winter pea mixture on 8 Sept. and 7 Oct. in 2009, and on 11 May, 27 May, 18 June, and 6 July in 2010. Alleyways in the offset cultivator treatment were cultivated with the control treatment on 26 Mar. 2009 and 16 Mar. 2010 and mowed on the same date as other cover crops thereafter. A small percentage of vines $(<5 \%)$ were lost because of graft union breakage or damage caused by string-trimming. Data were collected from the adjacent vine within the same treatment, and dead vines were replaced during the winter dormant season.
Weed and cover crop biomass collections were made in representative areas of the alleyway and in-row areas of each subplot on 3 Aug. and 27 Sept. 2009 and on 22 July and 27 Sept. 2010. Two $0.13 \mathrm{~m}^{2}$ quadrats were placed in each subplot and all aboveground vegetation was clipped. The clipped vegetation was sorted by species and dried at $35^{\circ} \mathrm{C}$ for $\approx 3 \mathrm{~d}$, after which dry weight was recorded. The time needed for weed and cover crop maintenance was recorded in both years for all treatments, to compare the labor requirements for hand weeding and use of string-trimmer or specialty cultivator. Weed suppression, grapevine shoot length, and maintenance time were ranked in order for each alleyway management treatment, and the overall average rank was calculated.

All data were subjected to PROC GLM and PROC MIXED where appropriate, using JMP (version 9.0; SAS Institute, Cary, NC). Data were transformed as necessary to ensure that normality was satisfied. The whole plot factor was weed suppression treatment and the subplot factor was grape cultivar. Main effects and interactions were tested for significance; data with significant interactions were subjected to means separation using Tukey's honestly significant difference test at $P \leq 0.05$.

\section{Results and discussion}

COVER CROP AND WEED BIOMASS. Cover crop and weed dry biomass differed significantly by treatment and row location on almost all dates in both years $(P \leq 0.05)$ but was not influenced by grape cultivar (data not shown), thus all data were combined for analysis. In 2009, the companion grass cover crop mix did not establish because of droughty conditions and no cover crop was detected in the offset cultivator treatment on either sample date. Austrian winter pea biomass in the alleyway on 3 Aug. was four times greater in the austrian winter pea treatment than in winter wheat-austrian winter pea mixture (Table 1) and in-row biomass of the austrian winter pea treatment was three times greater than in the winter wheat-austrian winter pea mixture (Table 1). In addition, biomass in the austrian winter pea treatment was $40 \%$ greater in the alleyway than in-row, reflecting the higher seeding rate in the alleyway as compared with in-row. In the winter wheat-austrian winter pea mixture, austrian winter pea biomass was similar in the alleyway and in-row suggesting that austrian winter pea did not become well established in the alleyway, perhaps due to competition with winter wheat (Akemo et al., 2000).

By 27 Sept., austrian winter peas were eliminated in both the sole austrian winter pea treatment and the winter wheat-austrian winter pea mixture treatments. In contrast, winter wheat dry biomass was about equal in the alleyways of the winter wheat and winter wheat-austrian winter pea mixture treatments on 3 Aug. (Table 1), despite the 33\% higher seeding rate in the winter wheat treatment suggesting that a $200 \mathrm{lb} /$ acre seeding rate was adequate for the establishment of the winter wheat cover crop. In the winter wheat and winter wheat-austrian winter pea mixture treatments, winter wheat biomass was about twice as great in the alleyway as in-row during both sampling periods reflecting the higher seeding rate in the alleyway as compared with in-row (Table 1).

Primary weed species collected in all treatment plots in 2009 were common lambsquarters (Chenopodium album), shepherd's-purse (Capsella bursa-pastoris), ladysthumb (Polygonum persicaria), pale smartweed (Persicaria lapathifolium), and henbit (Lamium amplexicaule); dry biomass of these species is presented collectively as "other weeds" in Table 1 . Weed biomass in the alleyway on 3 Aug. tended to be lowest in the control and offset cultivator treatments (Table 1), but was not significantly different on 27 Sept. from other treatments as a result of the large variation in recovery of weed biomass. In alleyways and in-row, weeds accounted for almost $100 \%$ of the biomass in the control and offset cultivator treatments, $42 \%$ to $60 \%$ in the austrian winter pea treatment, $33 \%$ to $55 \%$ in the winter wheat treatment, and $21 \%$ to $48 \%$ in winter wheat-austrian winter pea mixture treatment. In general, two times greater weed biomass was found in-row than in the alleyway of all treatments.

These shifts in winter wheat and austrian winter pea populations between the first and second sampling reflect both the biological life cycle of 
Table 1. Mean dry aboveground biomass of cover crop and weeds in alleyways and within grapevine rows under alleyway and in-row management regimes in $2009 .^{2}$

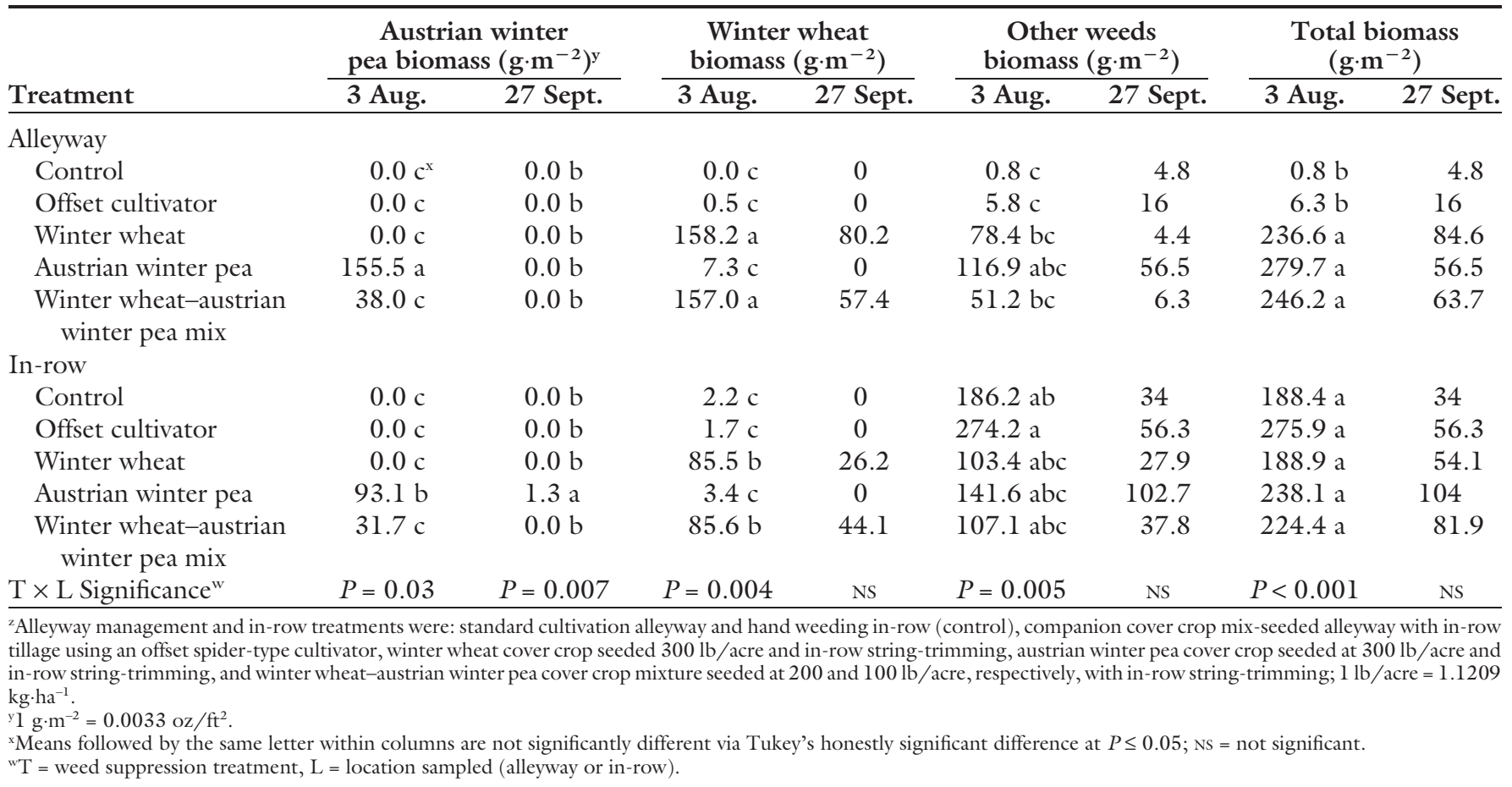

each crop and the management techniques used. Austrian winter pea is a relatively short-lived annual, while winter wheat is a relatively long-lived annual crop. The mowing and stringtrimming of the cover crop treatments most likely eliminated the shoot meristem of austrian winter peas, which is located at the apical portion of the plant, while the growing point of winter wheat is at the distal portion (base) of the plant.

In 2010, although both winter wheat and austrian winter pea were seeded in plots on 23 Mar., significant biomass of these crops was not found in the respective treatments on 22 July (data not shown). Maintenance programs coupled with poor cover crop stand establishment and competition from two weed species, white clover and perennial ryegrass, appeared to have eliminated the annual cover crops by mid-July. Because of their abundance, biomass of white clover and perennial ryegrass are reported separately, while biomass of common lambsquarters, shepherd's-purse, pale smartweed, and panicled willowherb (Epilobium brachycarpum) are presented collectively as "other weeds" (Table 2). Perennial ryegrass was part of the companion cover crop mix seeded in the offset cultivator treatment, whereas annual ryegrass (Lolium multiflorum) was a common weed species present at the site. Separation and identification of these two grasses with certainty was not possible due to lack of reproductive features at the time of biomass sampling. In this study, the perennial ryegrass biomass in the alleyway of the offset cultivator treatment is considered to be the intentionally seeded perennial ryegrass cover crop, while the annual ryegrass in all other locations is considered to be a weed.

Cover crop perennial ryegrass biomass in the alleyway of the offset cultivator treatment was unchanged over the sample period (Table 2). Total biomass in the alleyway on both dates tended to be lowest in the control and was four times lower than in all other treatments (Table 2). Total in-row biomass on both dates also tended to be lowest in control and offset cultivator treatments and was at least eight times lower than in all other treatments. Of the total biomass in the control on both dates, an average of $85 \%$ was other weeds in the alleyway and $79 \%$ were other weeds in-row. In the offset cultivator treatment, white clover biomass was 19\% greater than other weeds in the alleyway on both dates, and $41 \%$ greater in-row. In the alleyway of the winter wheat, austrian winter pea, and winter wheat-austrian winter pea mixture treatments on both dates, the total biomass averaged 39\% white clover, $25 \%$ perennial ryegrass, and $36 \%$ other weeds. In-row of the winter wheat, austrian winter pea, and winter wheat-austrian winter pea mixture treatments, the total biomass averaged $57 \%$ white clover, $27 \%$ perennial ryegrass, and $16 \%$ other weeds. Biomass of other weeds in the alleyway of all treatments except the control declined $50 \%$ on average on 27 Sept. as compared with 22 July to 27 Sept., potentially because of the increased competition from white clover, which increased 2- to 6-fold between the two sampling dates.

These results reflect the loss of seeded annual cover crops throughout the growing season and the ability of white clover to become established in a mowed system. Annual ryegrass biomass was greatest in the austrian winter pea alleyway and in-row on both dates, reflecting the invasiveness of annual ryegrass when minimal competition exists from a cover crop. This is of particular concern as glyphosate and glufosinate-resistant annual ryegrass species are found in the Pacific northwestern United States (AvilaGarcia and Mallory-Smith, 2011). Although the research vineyard located at WSU-NWREC was in transition to organic certification, fields 
surrounding the vineyard are not certified organic and incorporate nonorganic herbicides. It is essential that a good cover crop stand is established to be effective in preventing weed seed germination (Brennan and Smith, 2005; Teasdale, 1993; Teasdale and Daughtry, 1993). Narrow row spacing precluded the use of a grain drill to seed cover crops in this trial, but availability of narrow width seeding equipment might result in more effective cover crops establishment in a young vineyard, particularly in the second year and beyond.

GrAPEVINE SHOOT LENGTH AND PRUNING WEIGHT. Shoot length differed because of alleyway management treatment and cultivar on almost all sample dates in both years $[P \leq 0.05$ (Figs. 1 and 2)] and there were no interactions between alleyway management treatments and cultivars (data not shown). 'Madeleine angevine' shoot growth was $\approx 66 \%$ greater than that that for 'Pinot noir précoce' throughout the season in 2009 and $\approx 20 \%$ greater in $2010(P \leq 0.05)$. In this study, 'Madeleine angevine' exhibited good shoot growth and canopy development while 'Pinot noir précoce' was less vigorous, as previously reported by Kliewer and Dokoozlian, (2005).

Table 2. Mean dry aboveground biomass of white clover, perennial ryegrass, other weeds and the combined total of all weeds within grapevine rows or in alleyways under alleyway and in-row management regimes in 2010 . $^{\mathrm{z}}$

\begin{tabular}{|c|c|c|c|c|c|c|c|c|}
\hline \multirow[b]{2}{*}{ Treatment } & \multicolumn{2}{|c|}{$\begin{array}{c}\text { White clover } \\
\text { biomass }\left(\mathrm{g} \cdot \mathrm{m}^{-2}\right)^{\mathrm{y}}\end{array}$} & \multicolumn{2}{|c|}{$\begin{array}{l}\text { Perennial ryegrass }{ }^{\mathrm{x}} \\
\text { biomass }\left(\mathrm{g} \cdot \mathrm{m}^{-2}\right)\end{array}$} & \multicolumn{2}{|c|}{$\begin{array}{c}\text { Other weeds } \\
\text { biomass }\left(\mathrm{g} \cdot \mathrm{m}^{-2}\right) \\
\end{array}$} & \multicolumn{2}{|c|}{$\begin{array}{l}\text { Total biomass } \\
\left(\mathrm{g} \cdot \mathrm{m}^{-2}\right)\end{array}$} \\
\hline & 22 July & 27 Sept. & 22 July & 27 Sept. & 22 July & 27 Sept. & 22 July & 27 Sept. \\
\hline \multicolumn{9}{|l|}{ Alleyway } \\
\hline Control & 0.3 & 0 & $5.0 \mathrm{c}^{\mathrm{w}}$ & $4.8 \mathrm{~b}$ & 23.4 & 35.3 & $28.7 \mathrm{c}$ & $40.1 \mathrm{~b}$ \\
\hline Offset cultivator & 11.6 & 69.0 & $152.2 \mathrm{a}$ & $154.0 \mathrm{a}$ & 1.2 & 0.7 & $165.0 \mathrm{bc}$ & $223.7 \mathrm{ab}$ \\
\hline Winter wheat & 49.4 & 87.1 & $32.2 \mathrm{bc}$ & $16.5 \mathrm{~b}$ & 107.6 & 37.3 & $189.2 \mathrm{bc}$ & $140.9 \mathrm{ab}$ \\
\hline \multicolumn{9}{|l|}{ In-row } \\
\hline Control & 0.3 & 11.5 & $0.1 \mathrm{c}$ & $0.1 \mathrm{~b}$ & 20.2 & 17.0 & $20.6 \mathrm{c}$ & $28.6 \mathrm{~b}$ \\
\hline Offset cultivator & 25.7 & 6.2 & $19.3 \mathrm{bc}$ & $5.3 \mathrm{~b}$ & 8.2 & 7.1 & $53.2 \mathrm{c}$ & $18.6 \mathrm{~b}$ \\
\hline Winter wheat & 97 & 207.0 & $70.2 \mathrm{abc}$ & $73.0 \mathrm{ab}$ & 60.9 & 58.6 & $228.1 \mathrm{abc}$ & $338.6 \mathrm{a}$ \\
\hline
\end{tabular}

${ }^{\mathrm{z} A l l e y w a y ~ m a n a g e m e n t ~ a n d ~ i n-r o w ~ t r e a t m e n t s ~ w e r e: ~ s t a n d a r d ~ c u l t i v a t i o n ~ a l l e y w a y ~ a n d ~ h a n d ~ w e e d i n g ~ i n-r o w ~(c o n t r o l), ~ c o m p a n i o n ~ c o v e r ~ c r o p ~ m i x-s e e d e d ~ a l l e y w a y ~ w i t h ~ i n-r o w ~}$ tillage using an offset spider-type cultivator, winter wheat cover crop seeded $300 \mathrm{lb} /$ acre and in-row string-trimming, austrian winter pea cover crop seeded at $300 \mathrm{lb} / \mathrm{acre}$ and in-row string-trimming, and winter wheat-austrian winter pea cover crop mixture seeded at 200 and $100 \mathrm{lb} /$ acre, respectively, with in-row string-trimming; $1 \mathrm{lb} / \mathrm{acre}=1.1209$ $\mathrm{kg} \cdot \mathrm{ha}^{-1}$.

${ }^{\mathrm{y}} \mathrm{l} \mathrm{g} \cdot \mathrm{m}^{-2}=0.0033 \mathrm{oz} / \mathrm{ft}^{2}$.

${ }^{\mathrm{x}}$ Means in alleyway of CG treatment is perennial ryegrass cover crop while in all other treatments and locations annual ryegrass as a weed is reported.

"Means followed by the same letter or no letter within columns are not significantly different via Tukey's honestly significant difference at $P \leq 0.05$; Ns $=$ not significant.

${ }^{\mathrm{v}} \mathrm{T}$ = weed suppression treatment, $\mathrm{L}=$ location sampled (alleyway or in-row).

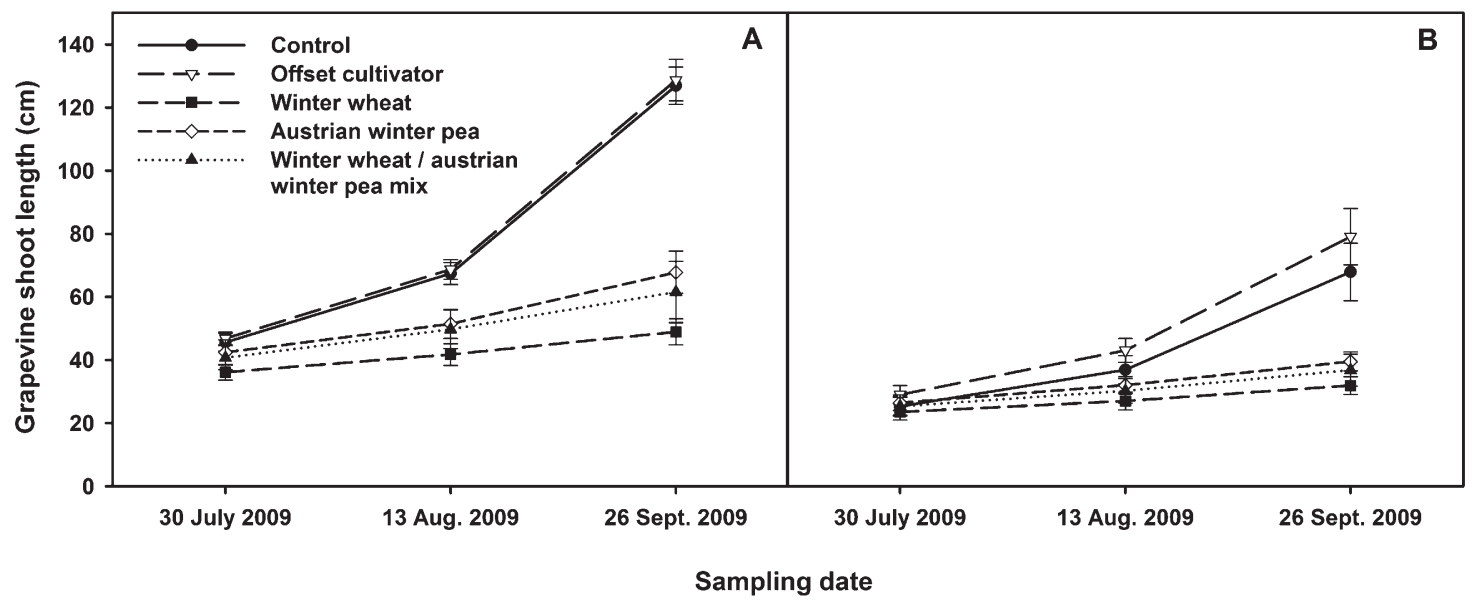

Fig. 1. Effect of alleyway and in-row management regimes on (A) 'Madeleine angevine' and (B) 'Pinot noir précoce' grapevine shoot length in 2009. Regimes included standard cultivation alleyway and hand weeding in-row (control), companion cover crop mix-seeded alleyway with in-row tillage using an offset spider-type cultivator (offset cultivator), winter wheat cover crop seeded $300 \mathrm{lb} /$ acre and in-row string-trimming, austrian winter pea cover crop seeded at $300 \mathrm{lb} / \mathrm{acre}$ and in-row stringtrimming (pea), and winter wheat-austrian winter pea cover crop mixture seeded at 200 and $100 \mathrm{lb} / \mathrm{acre}$, respectively, with inrow string-trimming; $1 \mathrm{lb} /$ acre $=1.1209 \mathrm{~kg} \cdot \mathrm{ha}^{-1}, 1 \mathrm{~cm}=0.3937$ inch . 


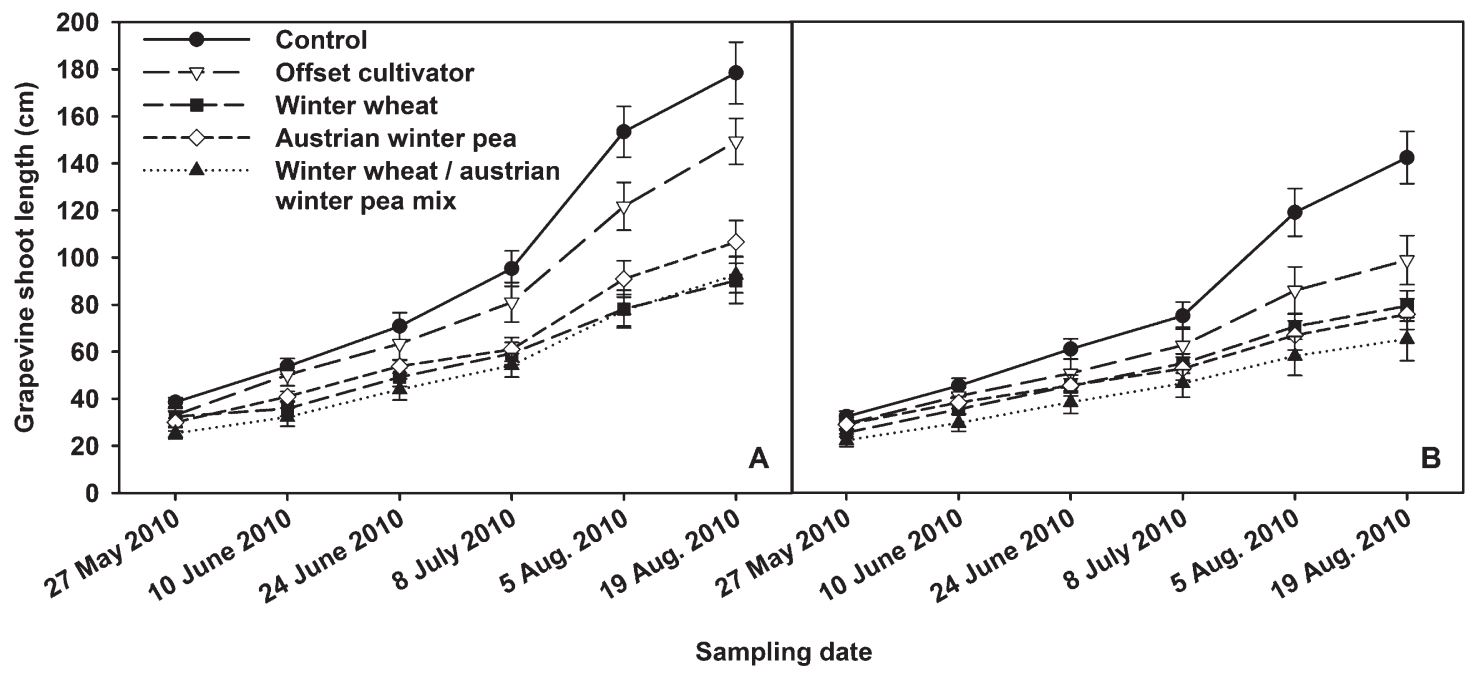

Fig. 2. Effect of alleyway and in-row management regimes on (A) 'Madeleine angevine' and (B) 'Pinot noir précoce' grapevine shoot length in 2010. Regimes included standard cultivation alleyway and hand weeding in-row (control), companion cover crop mix-seeded alleyway with in-row tillage using an offset spider-type cultivator (offset cultivator), winter wheat cover crop seeded $300 \mathrm{lb} /$ acre and in-row string-trimming, austrian winter pea cover crop seeded at $300 \mathrm{lb} / \mathrm{acre}$ and in-row stringtrimming, and winter wheat-austrian winter pea cover crop mixture seeded at 200 and $100 \mathrm{lb} / \mathrm{acre}$, respectively, with in-row string-trimming; $1 \mathrm{lb} /$ acre $=1.1209 \mathrm{~kg} \cdot \mathrm{ha}^{-1}, 1 \mathrm{~cm}=0.3937 \mathrm{inch}$.

In 2009, shoot length for 'Madeline angevine' was unaffected by alleyway management treatment on 30 July, but on 13 Aug. and 26 Sept., shoot length was greatest in the control and offset cultivator treatments followed by the austrian winter pea, winter wheat-austrian winter pea mixture, and winter wheat treatments (Fig. 1A). Shoot growth of 'Pinot noir précoce' also did not differ on 30 July, but by 26 Sept. was greatest in offset cultivator and control treatments (Fig. 1B). In 2010, on all sample dates except 27 May, 'Madeline angevine' shoot length was greatest in the control, followed by the offset cultivator, austrian winter pea, winter wheat, and winter wheat-austrian winter pea mixture treatments (Fig. 2A), while for 'Pinot noir précoce', shoot length was greatest in the control followed by the offset cultivator, winter wheat, austrian winter pea, and winter wheataustrian winter pea mixture treatments (Fig. 2B).

In both years, shoot length and pruning weight was greater in the control and offset cultivator treatments for both 'Madeline angevine' and 'Pinot noir précoce' (Figs. 1 and 2 , Table 3 ), underscoring the importance of reducing competition within the row of young vineyards (Bordelon and Weller, 1997). In 2010, while total in-row groundcover biomass was similar between the control and offset

Table 3. Effect of alleyway and in-row management regimes on 'Madeleine angevine' and 'Pinot noir précoce' total pruning weight in 2009 and $2010 .{ }^{\mathrm{z}}$

\begin{tabular}{lcc}
\hline & \multicolumn{2}{c}{ Pruning wt $(\mathbf{k g})^{\mathrm{y}}$} \\
\cline { 2 - 3 } & $\mathbf{2 0 0 9}$ & $\mathbf{2 0 1 0}$ \\
\hline 'Madeleine Angevine' & $17.9 \mathrm{a}^{\mathrm{x}}$ & $5.3 \mathrm{ab}$ \\
Control & $16.6 \mathrm{ab}$ & $2.8 \mathrm{bc}$ \\
Offset cultivator & $3.0 \mathrm{cdef}$ & $0.5 \mathrm{c}$ \\
Winter wheat & $5.4 \mathrm{~cd}$ & $0.9 \mathrm{c}$ \\
Austrian winter pea & $4.5 \mathrm{cde}$ & $1.0 \mathrm{c}$ \\
Winter wheat-austrian winter pea mix & & $6.4 \mathrm{a}$ \\
'Pinot noir précoce' & $5.3 \mathrm{bcd}$ & $3.3 \mathrm{abc}$ \\
Control & $6.1 \mathrm{abc}$ & $1.2 \mathrm{c}$ \\
Offset cultivator & $1.1 \mathrm{f}$ & $1.3 \mathrm{c}$ \\
Winter wheat & $1.9 \mathrm{def}$ & $1.0 \mathrm{c}$ \\
Austrian winter pea & $1.4 \mathrm{ef}$ \\
Winter wheat-austrian winter pea mix & & $\mathrm{ald}$ \\
\hline
\end{tabular}

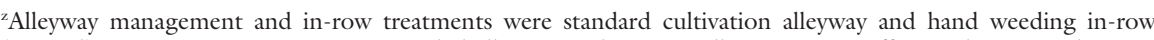
(control), companion cover crop mix-seeded alleyway with in-row tillage using an offset spider-type cultivator, winter wheat cover crop seeded $300 \mathrm{lb} /$ acre and in-row string-trimming, austrian winter pea cover crop seeded at $300 \mathrm{lb} / \mathrm{acre}$ and in-row string-trimming, and winter wheat-austrian winter pea cover crop mixture seeded at 200 and $100 \mathrm{lb} / \mathrm{acre}$, respectively, with in-row string-trimming; $1 \mathrm{lb} / \mathrm{acre}=1.1209 \mathrm{~kg} \cdot \mathrm{ha}^{-1}$.

${ }^{y} \mathrm{lgg}=2.2046 \mathrm{lb}$.

${ }^{x}$ Means followed by the same letter or no letter within columns are not significantly different via Tukey's honestly significant difference at $P \leq 0.05$.

cultivator treatments, biomass in the alleyway was almost six times greater in the offset cultivator treatment than in the control (Table 2). This suggests that presence of perennial ryegrass cover crop in the offset cultivator treatment was responsible for the difference in shoot growth during the second season of vineyard establishment. Even in mature vineyards, competition from planted alleyways can reduce vine root growth into the alleyways thereby limiting vine root access to nutrient and soil structure benefits of the alleyway (Morlat and Jacquet, 2003). In certain high-vigor situations in mature vineyards, increased competition because of cover crops is desired and can mitigate imbalances in shoot growth and crop load (Hatch et al., 2011; Tesic et al., 2007). However, during vineyard establishment competition from weeds and cover crops should be kept at a minimum to encourage formation of the grapevine permanent structure. 
AlLeyWAY MANAGEMENT MAINTENANCE REQUIREMENTS. The least amount of maintenance time occurred in the winter wheat, austrian winter pea, and winter wheataustrian winter pea mixture treatments as compared with control and offset cultivator treatments (Table 4). In 2009, more time was spent hand weeding than on any other task in control and offset cultivator treatments. In 2010, the greatest percentage of time $(41 \%)$ spent in winter wheat, austrian winter pea, and winter wheat-austrian winter pea mixture treatments was for string-trimming (Table 4); however, the most time spent on a single task was in-row hand weeding in the control treatment $\left(73.6 \mathrm{~h} \cdot \mathrm{ha}^{-1}\right)$. The specialty cultivator effectively reduced in-row weeding time as hand weeding in the control treatment took over twice as long as in the offset cultivator treatment during 2009 , and about five times as long in 2010. In 2010, $58 \mathrm{~h} \cdot \mathrm{ha}^{-1}$ were spent operating the specialty cultivator in the offset cultivator treatment. When averaged across treatments, in-row maintenance took 19 times longer than in the alleyway in 2009 and four times longer in 2010 . It is also important to note that operating the specialty cultivator for in-row weed management is far less physically taxing than hand weeding. Additionally, string-trimming in-row areas of winter wheat, austrian winter pea, and winter wheat-austrian winter pea mixture resulted in $2 \%$ accidental grapevine

Table 4. Mean annual maintenance labor including mowing, disking, in-row cultivating, hand weeding, and string-trimming for vineyard alleyway and inrow management regimes in 'Madeleine angevine' and 'Pinot noir précoce' grapevine in 2009 and $2010 .^{\mathrm{z}}$

\begin{tabular}{|c|c|c|}
\hline & \multicolumn{2}{|c|}{ Mean annual labor required $\left(h \cdot h a^{-1}\right)^{y}$} \\
\hline & 2009 & 2010 \\
\hline \multicolumn{3}{|l|}{ Treatment } \\
\hline Control & $79.7 \mathrm{a}^{\mathrm{x}}$ & $104.2 \mathrm{a}$ \\
\hline Offset cultivator & $47.2 \mathrm{~b}$ & $81.2 \mathrm{ab}$ \\
\hline Winter wheat & $12.8 \mathrm{c}$ & $52.0 \mathrm{~b}$ \\
\hline Austrian winter pea & $18.4 \mathrm{c}$ & $66.3 \mathrm{~b}$ \\
\hline $\begin{array}{l}\text { Winter wheat-austrian } \\
\text { winter pea mix }\end{array}$ & $18.4 \mathrm{c}$ & $62.3 \mathrm{~b}$ \\
\hline \multicolumn{3}{|l|}{ Location } \\
\hline Alleyway & $3.5 \mathrm{~b}$ & $27.54 \mathrm{~b}$ \\
\hline In-row & $67.1 \mathrm{a}$ & $118.9 \mathrm{a}$ \\
\hline \multicolumn{3}{|c|}{ 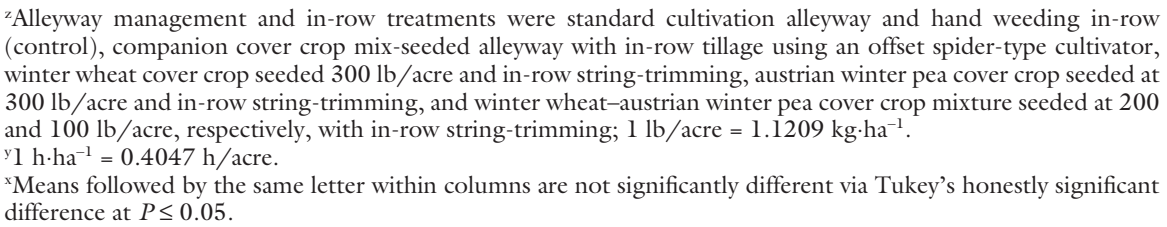 } \\
\hline
\end{tabular}

death (28 vines) during 2009 when vines were tender and more easily damaged, but no accidental vine kill occurred in 2010 as the vines increased in trunk diameter. There was no difference in maintenance requirements between grape cultivars (data not shown).

RANKING OF TREATMENT EFFECTIVENESS. Weed suppression was most effective in the control, followed by the offset cultivator, winter wheat-austrian winter pea mixture, winter wheat, and austrian winter pea treatments (Table 5). Shoot growth was greatest in the control, followed by the offset cultivator, austrian winter pea, winter wheat, and winter wheat-austrian winter pea mixture treatments. Maintenance time was least in the winter wheat treatment, followed by the winter wheat-austrian winter pea mixture, austrian winter pea, offset cultivator, and control. Based on the combined ranking of all three factors, the overall rank of alleyway management treatments were the control, offset cultivator, winter wheat, winter wheat-austrian winter pea mixture, and austrian winter pea. These results indicate an inverse relationship between weed biomass and time, and between shoot length and weed biomass. That is, more maintenance time is required to reduce weed biomass, and lower weed biomass resulted in greater shoot growth.

In this study, winter wheat persisted better in alleyways than in-row, indicating that string-trimming to the soil level caused more injury to winter wheat than mowing at 2 inches. Austrian winter pea was eliminated in both the alleyway and in-row due to mowing and string-trimming,

Table 5. Ranked order of combined alleyway and in-row management regimes based on total weed biomass, grapevine shoot length, and mean maintenance labor required combined for 2009 and $2010 .^{\mathrm{z}}$

\begin{tabular}{|c|c|c|c|c|c|c|c|c|}
\hline \multirow[b]{2}{*}{ Treatment } & \multicolumn{2}{|c|}{ Weed suppression } & \multicolumn{2}{|c|}{ Grapevine shoot length } & \multicolumn{2}{|c|}{ Maintenance time } & \multirow[b]{2}{*}{ Avg rank } & \multirow[b]{2}{*}{$\begin{array}{c}\text { Overall } \\
\text { rank }\end{array}$} \\
\hline & $\begin{array}{c}\text { Total weed } \\
\text { biomass }\left(\mathrm{g} \cdot \mathrm{m}^{-2}\right)^{\mathrm{y}}\end{array}$ & $\operatorname{Rank}^{\mathrm{x}}$ & $\begin{array}{l}\text { Final shoot } \\
\text { length }(\mathrm{cm})^{\mathrm{y}}\end{array}$ & Rank & $\begin{array}{l}\text { Total maintenance } \\
\text { time }\left(h \cdot h a^{-1}\right)^{y}\end{array}$ & Rank & & \\
\hline Control & 344 & 1 & 160.4 & 1 & 183.94 & 5 & 2.3 & 1 \\
\hline Offset cultivator & 507 & 2 & 124.8 & 2 & 128.41 & 4 & 2.7 & 2 \\
\hline Winter wheat & 1,111 & 4 & 84.8 & 4 & 64.81 & 1 & 3 & 3 \\
\hline Austrian winter pea & 1,363 & 5 & 91.2 & 3 & 84.64 & 3 & 3.7 & 5 \\
\hline
\end{tabular}

winter pea mix

${ }^{\text {z} A l l e y w a y ~ m a n a g e m e n t ~ a n d ~ i n-r o w ~ t r e a t m e n t s ~ w e r e ~ s t a n d a r d ~ c u l t i v a t i o n ~ a l l e y w a y ~ a n d ~ h a n d ~ w e e d i n g ~ i n-r o w ~(c o n t r o l), ~ c o m p a n i o n ~ c o v e r ~ c r o p ~ m i x-s e e d e d ~ a l l e y w a y ~ w i t h ~ i n-r o w ~}$ tillage using an offset spider-type cultivator, winter wheat cover crop seeded $300 \mathrm{lb} / \mathrm{acre}$ and in-row string-trimming, austrian winter pea cover crop seeded at $300 \mathrm{lb} / \mathrm{acre}$ and in-row string-trimming, and winter wheat-austrian winter pea cover crop mixture seeded at $200 \mathrm{and} 100 \mathrm{lb} / \mathrm{acre}$, respectively, with in-row string-trimming; $1 \mathrm{lb} / \mathrm{acre}=1.1209$ $\mathrm{kg} \cdot \mathrm{ha}^{-1}$.

${ }^{y} 1 \mathrm{~g} \cdot \mathrm{m}^{-2}=0.0033 \mathrm{oz} / \mathrm{ft}^{2}, \mathrm{l} \mathrm{cm}=0.3937 \mathrm{inch}, \mathrm{l} \mathrm{h} \cdot \mathrm{ha}^{-1}=0.4047 \mathrm{~h} /$ acre.

${ }^{\mathrm{x}} \mathrm{l}=$ best performance within a category, 5 = poorest performance within a category. 
respectively. Under the maintenance regimes used in this study, the lifespans of austrian winter pea and winter wheat were about three months, suggesting that these cover crops are not well suited to vineyard systems where weed control is needed for a longer period of time. This is especially true in western Washington where weed growth occurs year-round. An alternative strategy to single plantings of short-lived cover crops is to stagger plantings of similar-lived cover crop cultivars throughout the growing season to provide continual weed suppression.

In a newly established organic vineyard, the most effective weed suppression technique allowing for maximum vine shoot growth would be clean cultivation based on results in this study. However, labor efficiency must be taken into consideration when establishing a high-value enterprise such as a vineyard. Including a vegetation-free zone using a specialty cultivator can minimize the time needed for in-row hand weeding, while still allowing for good vine shoot growth. Another option would be to use conventional production techniques that use synthetic herbicides during the establishment phase, and once established, transition the vineyard to achieve organic certification. Further research is needed to identify cover crops that suppress annual and perennial weed species in the alleyway and that do not reduce shoot growth during the establishment years. A perennial cover crop that is maintained by mowing may be more labor efficient and environmentally sustainable than the cultivation and reseeding that is required for annual cover crops.

\section{Literature cited}

Akemo, M.C., E.E. Regnier, and M.A. Bennett. 2000. Weed suppression in spring-sown rye (Secale cereale): Pea (Pisum sativum) cover crop mixes. Weed Technol. 14:545-549.

Altieri, M.A. 1995. Agroecology: The science of sustainable agriculture. Westview Press. Boulder, CO.

Avila-Garcia, W. and C. Mallory-Smith. 2011. Glyphosate-resistant Italian ryegrass (Lolium perenne) populations also exhibit resistance to glufosinate. Weed Sci. 59:305-309.
Balerdi, C.F. 1972. Weed control in young vineyards. Amer. J. Enol. Viticult. $23: 58-60$.

Bolton, C. 2011. Organic weed control in a newly established vineyard. Washington State University, Pullman, MS Thesis.

Bordelon, B.P. and S.C. Weller. 1997. Preplant cover crops affect weed and vine growth in first-year vineyards. HortScience 32:1040-1043.

Brennan, E.B. and R.F. Smith. 2005. Winter cover crop growth and weed suppression on the central coast of California. Weed Technol. 19:1017-1024.

Bugg, R.L., G. McGourty, M. Sarrantonio, W.T. Lanini, and R. Bartolucci. 1996. Comparison of 32 cover crops in an organic vineyard on the north coast of California. Biol. Agr. Hort. 13:63-81.

Buhler, D.D. 1997. Effects of tillage and light environment on emergence of 13 annual weeds. Weed Technol. 11:496-501.

Byrne, M.E. and G.S. Howell. 1978. Initial response of Baco Noir grapevines to pruning severity, sucker removal, and weed control. Amer. J. Enol. Viticult. 29: 192-198.

Cordero-Bueso, G., T. Arroyo, A. Serrano, J. Tello, I. Aporta, M.D. Vélez, and E. Valero. 2011. Influence of the farming system and vine variety on yeast communities associated with grape berries. Intl. J. Food Microbiol. 145:132-139.

Dastgheib, F. and C. Frampton. 2000. Weed management practices in apple orchards and vineyards in the South Island of New Zealand. N. Z. J. Crop Hort. Sci. 28:53-58

Davies, M., K. Smith, and A. Vinten. 2001. The mineralization and fate of nitrogen following ploughing of grass and grass-clover swards. Biol. Fertil. Soils $33: 423-434$.

Delmas, M.A. and L.E. Grant. 2010. Ecolabeling strategies and price-premium: The wine industry puzzle. Bus. Soc. 1-39.

Dufour, R. 2006. Grapes: Organic production. Natl. Sustainable Agr. Info. Serv. Bul. IP031. 7 Oct. 2011. <https://attra. ncat.org/attra-pub/summaries/summary. php?pub=5\#weeds $>$.

Eastham, J., A. Cass, S. Gray, and D. Hansen. 1996. Influence of raised beds, ground cover and irrigation on growth and survival of young grapevines. Acta Hort. 427:37-44.

Fredrikson, L., P.A. Skinkis, and E. Peachey. 2011. Cover crop and floor management affect weed coverage and density in an establishing Oregon vineyard. HortTechnology 21:208-216.
Gaffney, F.B. and M. Van Der Grinten. 1991. Permanent cover crop for vineyards, p. 32-33. In: W.L. Hargrove (ed.). Cover crops for clean water. Soil Conservation Soc., Ankeny, IA.

Granatstein, D., E. Kirby, and H. Willer. 2010. Current world status of organic temperate fruits. Acta Hort. 873:19-36.

Gulick, S.H., D.W. Grimes, D.S. Munk, and D.A. Goldhamer. 1994. Cover-cropenhanced water infiltration of a slowly permeable fine sandy loam. Soil Sci. Soc. Amer. J. 58:1539-1546.

Guthman, J. 2000. Raising organic: An agro-ecological assessment of grower practices in California. Agr. Human Values 17:257-266.

Hatch, T.A., C.C. Hickey, and T.K. Wolf. 2011. Cover crop, rootstock, and root restriction regulate vegetative growth of Cabernet Sauvignon in a humid environment. Amer. J. Enol. Viticult. 62:298311.

Kliewer, W.M. and N.K. Dokoozlian. 2005. Leaf area/crop weight ratios of grapevines: Influence on fruit composition and wine quality. Amer. J. Enol. Viticult. 56:170-181.

Konrad, H., B. Lindner, E. Bleser, and E. Rühl. 2003. Strategies in the genetic selection of clones and the preservation of genetic diversity within varieties. Acta Hort. 603:105-110.

Krauss, M., A. Berner, D. Burger, A. Wiemken, U. Niggli, and P. Mader. 2010. Reduced tillage in temperate organic farming: Implications for crop management and forage production. Soil Use Mgt. 26:12-20.

Lal, R., R.F. Follett, B.A. Stewart, and J.M. Kimble. 2007. Soil carbon sequestration to mitigate climate change and advance food security. Soil Sci. 172:943956.

Liebman, M. and A.S. Davis. 2000. Integration of soil, crop and weed management in low-external-input farming systems. Weed Res. 40:27-47.

McGourty, G. 2004. Cover cropping systems for organically farmed vineyards. 19 June 2012. <http://www. practicalwinery.com/septoct $04 /$ septoct 04p22.htm>.

Montgomery, D.R. 2007. Soil erosion and agricultural sustainability. Proc. Natl. Acad. Sci. USA 104:132-168.

Morlat, R. and A. Jacquet. 2003. Grapevine root system and soil characteristics in a vineyard maintained long-term with or without interrow sward. Amer. J. Enol. Viticult. 54:1-7. 
Moulton, G.A. and J. King. 2005. Growing wine grapes in maritime western Washington. Washington State Univ. Ext. Bul. 2001.

Nevens, F. and D. Reheul. 2002. The nitrogen contribution effect of ploughed grass leys on the following arable forage crops: Determination and optimum use. Eur. J. Agron. 6:57-74

Olmstead, M.A., R.L. Wample, S.L. Greene, and J.M. Tarara. 2001. Evaluation of potential cover crops for inland Pacific Northwest vineyards. Amer. J. Enol. Viticult. 52:292-303.

Paoletti, M.G., D. Sommaggio, M.R. Favretto, G. Petruzzelli, B. Pezzarossa, and M. Barbafieri. 1998. Earthworms as useful bioindicators of agroecosystem sustainability in orchards and vineyards with different inputs. Appl. Soil Ecol. 10:137150 .

Pardini, A., C. Faiello, F. Longhi, S. Mancuso, and R. Snowball. 2002. Cover crop species and their management in vineyards and olive groves. Adv. Hort. Sci. 16:225-234.

Pimentel, D., P. Hepperly, J. Hanson, D. Douds, and R. Seidel. 2005. Environmental, energetic, and economic comparisons of organic and conventional farming systems. Bioscience 55:573-582.

Ripoche, A., A. Metay, F. Celette, and C. Gary. 2011. Changing the soil surface management in vineyards: Immediate and delayed effects on the growth and yield of grapevine. Plant Soil 339:259-271.

Snapp, S.S. and H. Borden. 2005. Enhanced nitrogen mineralization in mowed or glyphosate treated cover crops compared to direct incorporation. Plant Soil 270:101-112.

Steinmaus, S., C.L. Elmore, R.J. Smith, D. Donaldson, E.A. Weber, J.A. Roncoroni, and P.R.M. Miller. 2008. Mulched cover crops as an alternative to conventional weed management systems in vineyards. Weed Res. 48:273-281.

Stolz, H. and O. Schmid. 2007. Organic viticulture and winemaking: Development of environment and consumer friendly technologies for organic wine quality improvement and scientifically based legislative framework. 20 July 2012. <http://orgprints.org/10608/ 1/stolz-schmid-2007-ORWINE_d2.7_ consumers_research.pdf>.

Sweet, R.M. and R.P. Schreiner. 2010. Alleyway cover crops have little influence on Pinot noir grapevines (Vitis vinifera L.) in two western Oregon vineyards. Amer. J. Enol. Viticult. 61:240-252.

Tan, S. and G.D. Crabtree. 1990. Competition between perennial ryegrass sod and Chardonnay wine grapes for mineral nutrients. HortScience 25: $533-535$.

Teasdale, J.R. 1993. Interaction of light, soil moisture, and temperature with weed suppression by hairy vetch residue. Weed Sci. 41:46-51.

Teasdale, J.R. and C.S.T. Daughtry. 1993. Weed suppression by live and desiccated hairy vetch (Vicia villosa). Weed Sci. 41:207-212.

Teasdale, J.R. and C.L. Mohler. 1993 Light transmittance, soil temperature, and soil moisture under residue of hairy vetch and rye. Agron. J. 85:673-680.
Tesic, D., M. Keller, and R.J. Hutton. 2007. Influence of vineyard floor management practices on grapevine vegetative growth, yield, and fruit composition. Amer. J. Enol. Viticult. 58:1-11.

Triplett, G.B. and W.A. Dick. 2008. Notillage crop production: A revolution in agriculture! Agron. J. 100:153-165.

Washington State Department of Agriculture. 2012. Organic crop producer guidelines. 19 June 2012. <http://agr.wa.gov/ FoodAnimal/Organic/FoodProducers. aspx>.

Washington State University. 2011. Washington AVA growing degree days. 30 Dec. 2010. <http://wine.wsu.edu/ research-extension/weather/growingdegree-days $/>$.

White, G.B. 1996. The economics of converting conventionally managed vineyards to organic management practices. Acta Hort. 429:377-384.

Willer, H. and L. Kilcher. 2009. The World of organic agriculture. Statistics and emerging trends 2009. Forshungsinstitut für biologischen Landbau (FiBL), Frick, Switzerland-Intl. Federation of Organic Agr. Movements (IFOAM), Bonn, Germany.

Vargas, A.M., M.T. de Andrés, J. Borrego, and J. Ibáñez. 2009. Pedigrees of fifty table-grape cultivars. Amer. J. Enol. Viticult. 60:525-532.

Zabadal, T.J. 1999. Pest control in small vineyards. Michigan State Univ. Ext. Bul. 2698. 